\title{
Truth and transparency in a time of crisis
}

Lessons from history underline the importance of having direct lines of communication to and from public health officials, who must remain free from policital bias in times of crisis.

Brimming with patriotism about the Fourth Liberty Loan Drive parade on September 28, 1918, Philadelphians were excited to help fund the war that was supposed to end all wars. City officials knew by then that flu was coming, yet little was done until the epidemic was already underway (1). In the spring an illness named "Spanish influenza" had made its way across Europe. The disease did not originate in Spain - it only seemed to because Spain, a neutral country, enacted no wartime censorship to keep it secret. Over the summer, wartime censorship plus competition from a more interesting subject - the war — limited attention to the epidemic (1) (Figure 1). By early September, the Philadelphia Inquirer reported that 600 sailors were in the hospital with flu in Philadelphia. But the director of the Department of Health and Charities told the public it was unlikely the disease would spread to Philadelphia's civilians (1). Officials were confident they could confine it to the local military camps. Ten days before the parade, the Bureau of Health issued a warning about the flu, and a public campaign was initiated against coughing, sneezing, and spitting (1). Seven days prior to the parade, the Bureau of Health made influenza a reportable disease (1).

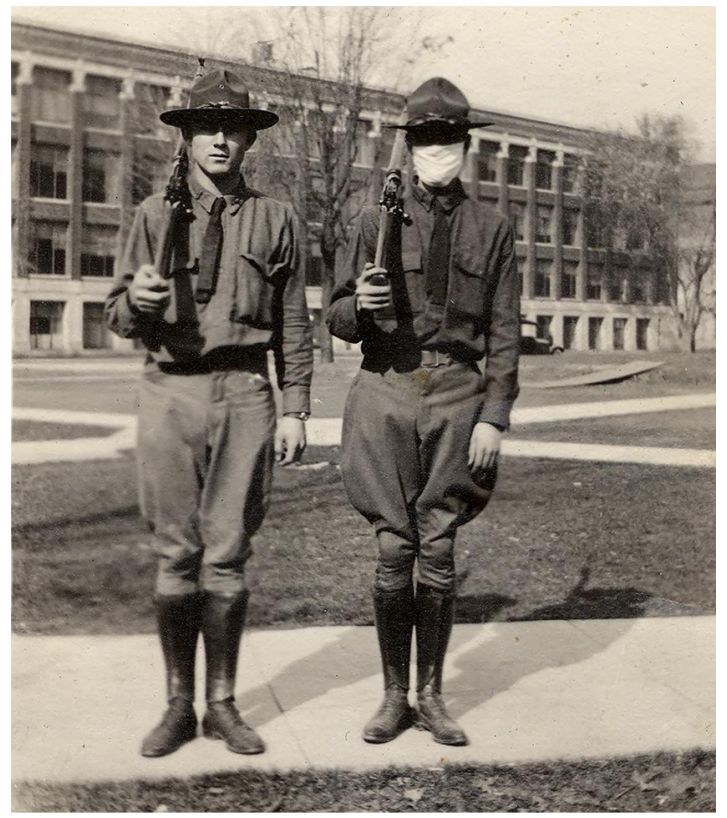

Figure 1. War and influenza simultaneously challenged the world in 1918. Two soldiers on the University of Michigan campus on Armistice Day, November 11, 1918. HS706, Caroline Maier Photograph Collection, Bentley Historical Library, University of Michigan.
Conflict of interest: The authors have declared that no conflict of interest exists.

Copyright: ( 2020 , American Society for Clinical Investigation.

Reference information: /CI Insight. 2020;5(6):e138132. https://doi. org/10.1172/jici.nsight.138132.
On the day of the parade, the Evening Bulletin unsurprisingly featured stories about the Allies making substantial advances against the Germans (2), while an article about a local police officer who had died of influenza was found on page 8 (2). Buoyed by news of success overseas, Philadelphians wanted to do what they could for the war effort; on September 28 , that meant attending the parade! The march that day would help provide the bonds desperately needed to fund the war effort.

Hundreds of thousands of people attended the parade. It was a joyful event. The spectators were not disappointed. But only days later, attitudes changed. Many became sick with influenza, and fear began to grip the city.

Weeks later the news was even worse. Eventually, over 10,000 Philadelphians died from influenza. Bodies were piled in cold storage plants and mass graves were dug (1). With the good intention of keeping up morale, health officers kept trying to reassure the public that all was well. After all, the cause of 
influenza was understood; Pfeiffer's bacillus had been identified in the lungs of patients infected with the Spanish flu (1). As we now know, Haemophilus influenza, its current name, was not the cause of the flu. But there was a remarkably high rate of secondary bacterial pneumonia associated with the $1918 \mathrm{flu}$ that contributed to the high death rate at a time when antibiotics were not available (3). It is not possible to know whether Philadelphians would have attended the parade on September 28, 1918, if they had had access to 21 st-century knowledge and had been able to make a more informed decision. However, well-timed efforts to use social distancing to limit the $1918 \mathrm{flu}$ epidemic in New York City later that same year appeared to reduce the impact of the outbreak in that city (4).

Like the Philadelphians of 1918, we are all making decisions based on information we receive about coronavirus (COVID-19). As of March 15, 2020, over 153,500 cases of COVID-19 infection have been reported from 100 countries worldwide (5). The disease poses tremendous challenges and questions to the global community. Should schools, restaurants, and movie theaters be closed? Should I have dinner with my neighbors? Should I move my elderly parents in with me? In medicine, physicians are trained to empower patients with the information they need to provide informed consent for a wide range of treatments and procedures. As a profession, we have moved from the belief that negative information should be withheld from a sick person to a belief that patients have a right to make up their own minds about their own health care. We have come to believe that patients need accurate information to make decisions that align with their own values. Health care providers are an important source of that information. Just as a functional, trusting, and transparent collaboration between physicians and their patients is necessary for informed consent, a trusting relationship must exist between our governmental health officials and the public. Efforts to suppress direct communication are detrimental to this goal.

These observations underline the need to ensure direct lines of communication to and from our public health officials. These officials must remain free of political bias so that their message is a transparent communication of facts. Transparency is a necessary condition of trust. And when trust is forfeited, so too is the opportunity to persuade people to alter behavior patterns for the common good.

Politicians on all sides of the political spectrum have agendas that can conflict with the aim of sharing facts that people need in order to make informed choices. Our public health officials, some of whom have served through multiple administrations across the political divide, must be protected from such concerns. It is imperative that they share their knowledge openly and safely. If they know good reasons for people to avoid parades, they must be permitted — and encouraged — to say so.

\section{Acknowledgments}

We thank Sarah Buss, Hank Paulson, Pavan Reddy, and Donna Martin for helpful discussions.

\section{Kathleen L. Collins, Editor}

Howard Markel, Center for the History of Medicine, University of Michigan Medical School Andrew P. Lieberman, Deputy Editor

\footnotetext{
1. Crosby AW. America's Forgotten Pandemic: The Influenza of 1918. 2nd ed. New York, New York, USA: Cambridge University Press; 2003

2. Navarro JA, Stern A, Markel H, eds. Influenza Encyclopedia: The American Influenza Epidemic of 1918-1919: A Digital Encyclopedia. 2nd ed. University of Michigan Center for the History of Medicine, Michigan Publishing, University of Michigan Library; September 2016. Accessed March 11, 2020. https://www.influenzaarchive.org.

3. Sheng ZM, et al. Autopsy series of 68 cases dying before and during the 1918 influenza pandemic peak. Proc Natl Acad Sci U S A. 2011;108(39):16416-16421.

4. Markel H, et al. Nonpharmaceutical interventions implemented by US cities during the 1918-1919 influenza pandemic. JAMA. 2007;298(6):644-654.

5. World Health Organization. Coronavirus Disease 2019 (COVID-19) Situation Report - 55. Coronavirus Disease 2019 website. https://www.who.int/docs/default-source/coronaviruse/situation-reports/20200315-sitrep-55-covid-19.pdf?sfvrsn=33daa5cb_8. March 15, 2020. Accessed March 17, 2020.
} 